\title{
The translation of philosophical texts
}

\section{Duncan Large}

\section{Introduction}

No philosophical tradition is an island: philosophy is an inherently multicultural and multilingual discipline. Many philosophers have had (or deliberately acquired) the linguistic equipment to understand philosophical texts written in languages other than their own, but in most cases the reception of foreign-language philosophy has depended on translations. Indeed, some philosophers would hardly have had any reception at all without translations (how many of Kierkegaard's readers outside Scandinavia read him in the original Danish?). ${ }^{1}$ This chapter will address some of the specific questions associated with the translation of philosophical texts. After a historical overview of some of the key translations that have changed the course of the development of philosophy, I will focus on three questions: 'why translate philosophy?', 'who translates philosophy?' and 'how to translate philosophy?'.

\section{Historical perspectives}

The history of philosophical translation in the west begins in the first century BCE with Roman translations and adaptations of Greek philosophy into Latin, and the creation of a new philosophical vocabulary in order to do so. As in most other cultural spheres, Roman philosophy exhibits a self-conscious and deferential desire to emulate prestigious Greek models (Seele 1995). Lucretius' (c. 99 - c. 55 BCE) epic didactic poem De rerum natura [On the Nature of Things] seeks to introduce Roman readers to Epicurean philosophy through a 


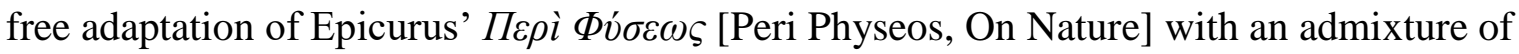
paraphrase and translation (Clay 1983, Sedley 1998). Rather than simply importing Greek words, with technical terms he is self-consciously innovating in order to create a philosophical vocabulary in Latin, through neologisms, calques, extensions of the meaning of existing words and other strategies. The poem itself explains the poet's predicament and blames it on the rudimentary state [egestas] of the Latin language:

Nor does it fail me that discoveries - obscure and dark Of Greeks are difficult to shed much light on with the spark Of Latin poetry, chiefly since I must coin much new Terminology, because of our tongue's dearth and due To the novelty of subject matter (Lucretius 2007: 10)

Lucretius' contemporary Cicero (106-43 BCE) faced the same problem and adopted the same solution, but from a more combative position. He was translating Greek oratory and philosophy (Epicurus, Xenophon, Plato, Aristotle) into Latin for an elite, educated (i.e. Greek-speaking) readership of free-born males who could be expected to be familiar with the source texts in their original language. In other words, at the outset of western philosophy translation the modern expectation that a text needed to be translated because it could not be understood in the source language did not apply. In his dialogue Academica [On Academic Scepticism, 45 BCE] Cicero explicitly raises the question of the need for Latin translations at all under such circumstances, when his fictional collocutor the lexicographer Varro asks:

For since I saw that philosophy had been most carefully expounded in Greek, I judged that any of our people who had an interest in this, if they were learned in the teachings of the Greeks, would sooner read Greek writings than ours, and if on the other hand they hated the sciences and systems of the Greeks, they would not care even for philosophy, which cannot be understood without Greek learning. (White 2015: 117, adapted) 
In response to such sceptics and nay-sayers, Cicero translates as a stylistic exercise, in order to develop the expressive potential and analytical precision of the Latin language, and to prove wrong those (such as Lucretius) who regretted the supposed poverty of the Latin language in relation to Greek by demonstrating instead the copiousness [abundantia] of a Latin lexis which could, as required, be exploited for philosophical purposes. Cicero uses multiple Latin translations for the single Greek term $\kappa \alpha \tau \alpha \dot{\lambda} \eta \psi \imath \varsigma$ [catalepsis] - cognitio, perceptio, comprehensio - but whereas earlier commentators denigrated this practice for its looseness, Georgina White (2015: 99-115) argues that this is a deliberate and habitual strategy asserting the relative superiority of Latin over Greek. Cicero was also unashamedly neologistic, coining terms such as essentia, evidentia, humanitas, perspicuitas and qualitas which would become mainstays of the Latin-language philosophical tradition.

After the classical period the transmission of Greek philosophy in the Latin West was very desultory. For around 800 years Plato was known almost exclusively through Calcidius's early 4th-century translation of the Timaeus, and Boethius' early 6th-century translations of Aristotle's works on logic were the only significant portions of his canon available to Christendom till the 12th century. Anglo-Saxon England saw a golden age of translation into the vernacular (Stanton 2002), with King Alfred looking to establish Old English as a literary language in the later 9 th century and taking the lead himself through translations of religious and philosophical works, including the first fifty psalms and the most popular philosophical work of the period, Boethius' Consolation of Philosophy (Discenza 2005). In general, philosophy translations into European vernacular languages were relatively few in the medieval period, but Boethius was a notable exception and attracted other celebrity translators including Notker Labeo (Old High German, c. 1000), Jean de Meun (Old French, 13c) and Geoffrey Chaucer (Middle English, late 14c) (Hoenen and Nauta 1997). Beyond 
Christendom, though, in late 8th-century Baghdad the Abbasid Caliph Harun al-Rashid established the House of Wisdom which, over the next century and a half, developed into not only the largest library in the world but the home of an ambitious translation project to translate (and retranslate) classics of science and philosophy from Greek (often via earlier Syriac translations) and Sanskrit into Arabic, in great quantities (Lyons 2009, Al-Khalili 2011). As Dimitri Gutas argues, the significance of the Graeco-Arabic translation movement 'lies in that it demonstrated for the first time in history that scientific and philosophical thought are international, not bound to a specific language or culture' (Gutas 1998: 192).

Translations of Aristotle into Arabic by Al-Kindī and his circle in Abbasid Baghdad gave a decisive impetus to the development of a specifically Islamic philosophy or falsafa (Adamson 2007, Alwishah and Hayes 2015). The 'Recovery of Aristotle' in the West came a good deal later and spanned roughly a century from the mid-12th to mid-13th centuries. Scholars working from Arabic and Byzantine Greek sources (in Toledo and elsewhere) translated most of the 'Corpus Aristotelicum' into Latin, leading to the rise of medieval Aristotelianism. At the same time, Latin translations of the Arabic-language Muslim philosophers Averroes and Avicenna were placed on the curriculum in the new universities of 13th-century Europe, and Averroist thought would persist into the Renaissance and beyond (Akasoy and Giglioni 2013). In the 15th century the European Renaissance was also initially fuelled by a spate of new Latin translations of Aristotle (Copenhaver 1988); the number of Renaissance humanists translating Plato was much smaller, but foremost among them was Marsilio Ficino, whose Complete Works of Plato in Latin (1484) fuelled Renaissance neo-Platonism.

In the 16th century, works of classical philosophy also began to be translated into European vernacular languages for the first time in significant quantities (Demetriou and Tomlinson 
2015). Just as Lucretius and Cicero, 1600 years earlier, had aimed to establish a philosophical tradition in Latin through translation, now the same impulse led Bible translator Antonio Brucioli (c. 1498-1566) to translate Aristotle into Italian (Bianchi, Gilson and Kraye 2016). In 1540 the French humanist Étienne Dolet (1509-46) published the first European treatise on translation (Worth 1988), and lumped French together with 'Italian, Spanish, German, English, and other vulgar tongues' as 'languages not yet established in the field of art' (Dolet 1992: 28), but in 16th-century France, 'under Francis I, enrichment of the French language became national policy' (Copenhaver 1988: 84). This led to such high-quality philosophical outputs as Dolet's own French Cicero (1542) and Plato (1544), Jacques Amyot's French Plutarch $(1559,1572)$ and Louis Le Roy's French Plato (1551-63). In contemporary England Nicholas Grimald published the first English translation of Cicero's popular De Officiis (1556) (Jones 1998), and several key works of Stoic philosophy appeared: James Sandford translated Epictetus's Manual (1567, from the French), Arthur Golding (translator of Shakespeare's Ovid) translated Seneca's De Beneficiis (1578), and Méric Casaubon the Meditations of Marcus Aurelius (1634). Philemon Holland (1552-1637) translated Plutarch's Moralia (1603), but the best known Renaissance English translation of Plutarch was Sir Thomas North's version of the Parallel Lives (1579, from Amyot's French) - best known because it, too, would be used by Shakespeare.

The other well-known example of an English philosophical translation used by Shakespeare, John Florio's version of the Essayes of Montaigne (1603), is a notable example of the first wave of philosophical translations between European vernacular languages, which would also include the first translations of Machiavelli - whom Shakespeare may have read in one of the four manuscript versions available in English by the close of the 16th century (Petrina 2009, De Pol 2010). The European Renaissance was indeed a golden age of translation, and this 
included first major translations from non-European languages, too, notably thanks to the work of Jesuit missionaries in translating Chinese classics, bringing them to the attention of western readerships (and packaging them as philosophy rather than religion). The Italians Michele Ruggieri (1543-1607) and Matteo Ricci (1552-1610) translated classic works of Confucianism and neo-Confucianism into Latin, and Jesuit philosophical Sinology culminated in the late 17th century with the publication of Confucius Sinarum Philosophus (Couplet 1687), a Latin anthology that included versions of three of the Four Books (the Great Learning, the Analects, and the Doctrine of the Mean) together with a biography of Confucius, edited by Flemish Jesuit Philippe Couplet. The Daoist classic Tao Te Ching now one of the most translated texts after the Bible - was first translated into a western language (again, Latin) c. 1720 by the French Jesuit Jean-François Noëlas (1669-1740). All this translation activity laid the groundwork for the considerable interest in China displayed by writers of the European Enlightenment such as Leibniz, Voltaire and Vico (Davis 1983, Perkins 2004, Harvey 2012, Mungello 2013, Brandt and Purdy 2016).

More overtly colonial European expansionism in the 18th and 19th centuries brought close contact with the philosophical cultures of India and Egypt. Whereas European understanding of the latter needed to wait till after Champollion's decipherment of hieroglyphic script in 1822 (the first translation of the ancient Egyptian Book of the Dead was Karl Richard Lepsius' German version from 1842), the opening up of India and its colonial exploitation by the East India Company from 1757 led to fruitful cultural contact by the end of the 18th century, such as the first translation into a European language of the Bhagavad Gita by the Orientalist Charles Wilkins (1785) and the development of the Indo-European language hypothesis (1786) by his colleague in the Asiatick Society of Bengal William Jones (Franklin 2011). The emergence of Indology, Orientalism more generally and comparative religion as 
academic disciplines by the turn of the 19th century, especially in Germany and France, led to another golden age for translation in German Romanticism. In 1808 Friedrich Schlegel prepared the way with his Über die Sprache und Weisheit der Indier [On the Language and Wisdom of the Indians] containing a partial translation of the Bhagavad Gita into German, but it was his brother August Wilhelm who - as well as being the 'Schlegel' in 'SchlegelTieck', the standard German set of Shakespeare translations - held the first chair of Indology in Germany (at the University of Bonn). A. W. Schlegel founded the scholarly journal Indische Bibliothek (1820-1830) and set up a Sanskrit printing press which he used to publish the first Sanskrit text in Europe, the Bhagavad Gita, in 1823 with his own Latin translation. The publication attracted a lot of interest in intellectual circles; Wilhelm von Humboldt gave two lectures on the text at the Royal Prussian Academy of Sciences in Berlin in June 1825 and June 1826, and it was the publication of these lectures in the Schriften der Berliner Akademie in 1827 that led Hegel to publish a substantial review in his periodical Jahrbücher für wissenschaftliche Kritik, in which he radically altered his earlier view on the significance of Indian philosophy (Herling 2006, Karyekar 2014, Rathore and Mohapatra 2017).

The first European-language translation of a Hindu text was a two-volume Latin retranslation and commentary of a Persian translation of fifty Upanishads, published in 1801-2 by Abraham Hyacinthe Anquetil-Duperron (1731-1805), the first professional French Indologist (Anquetil 2005). It was this edition that Arthur Schopenhauer encountered in March 1814 when he borrowed it from the library in Weimar; he subsequently bought and heavily annotated his own copy, which he considered his favourite book and which was to have a profound impact on the development of his own philosophy (Cartwright 2010: 265-76). Schopenhauer's follower Nietzsche inherited a favourable view of Indian philosophy from his mentor (see Parkes 1991). He had at least some familiarity with the Avesta (which had 
been available since 1771 in Anquetil-Duperron's French translation), and his respect for the historical Zoroaster led to his adopting 'Zarathustra' as his mouthpiece in Also sprach Zarathustra [Thus Spoke Zarathustra, 1883-5] (Rose 2000, Brobjer 2008: 65-66). Nietzsche was a close personal friend of the leading Indologist (and fellow Schopenhauerian) Paul Deussen, and read his ground-breaking translation of the Brahma Sutras on its publication in 1887 (Deussen 1887). Nietzsche's reading of Louis Jacolliot's French translation of the Law of Manu that same year (Jacolliot 1887) led directly to the favourable comments on Manu that he incorporated into his late texts Twilight of the Idols and The Antichrist (Elst 2008)and in turn led Nietzsche's correspondent the Swedish writer August Strindberg to write a novel on Nietzschean themes with the title Tschandala, first published in 1889 (in a Danish translation by Peter Nansen).

Another scion of German academic Indology, the distinguished Sanskritist F. Max Müller, began to translate the Upanishads while studying under F. W. J. Schelling in Berlin in the 1840s, but moved to Britain where he would become Oxford's first Professor of Comparative Philology in 1868 and the leading British mediator of Indian culture. Müller was renowned for his edition of the Rig-Veda (Müller 1849-74) and as general editor of the monumental 50volume series of translations The Sacred Books of the East (Müller 1879-1910; cf. Molendijk 2016, Davis and Nicholls 2017), which was inaugurated with his own translation of the Upanishads (Müller 1879-84). Müller's series included six volumes of The Sacred Books of China (1879-91), which were all translated by his prolific colleague the Scottish Sinologist James Legge, Oxford's first Professor of Chinese (Girardot 2002). While a missionary in Hong Kong, Legge had previously completed a five-volume bilingual edition of The Chinese Classics (1861-72), which was published in London by Nicholas Trübner, who would go on to publish many more philosophical translations in his collections 'English and Foreign 
Philosophical Library' (from 1877) and 'Trübner's Oriental Series' (from 1878). Not that the 19th-century translational traffic between Europe and the East was all one way: there was an influx of western philosophy into Japan in the late Tokugawa period and especially after the Meiji Restoration of 1868 , leading to what is described by Yūjirō Nakamura as a philosophical 'culture of translation' in Japan even now (cited Blocker and Starling 2001: 2; cf. Mayuko 2017). At the turn of the 20th century in China, Yan Fu (1854-1921), father of modern Chinese translation theory, was introducing secular western thought through highly influential translations of Thomas Huxley, Adam Smith, Herbert Spencer, John Stuart Mill and Montesquieu (Delisle and Woodsworth 2012: 209-12).

Within Europe, the development of British Idealism in the second half of the 19th century was fuelled by early English translations of Kant and Hegel (Mander 2011). In the twentieth century, to name just a few of the most prominent examples of translation-led cross-cultural philosophical fertilisation: translations of Wittgenstein and the Vienna Circle fuelled the development of logical positivism and analytic philosophy of language in the Englishspeaking world; in France, meanwhile, the phenomenological tradition developed through translations of Husserl and Heidegger (Large 2014: 187). The post-War vogue for Existentialism was fed by English-language translations of Sartre and Camus, and the later spread of 'continental' philosophy to the English-speaking world was only possible thanks to myriad translations of French structuralist, post-structuralist and postmodernist texts. Now the textual movement is going the other way, with the rapid spread of Anglo-American analytic philosophy translated into other European languages reversing the flow of the previous 50 years and reflecting the rapid increase in continental European interest in analytic philosophy over the last 30 years. 
In the 21 st century we have an embarrassment of riches: the philosophical canon is available in multiple translations and expanding all the time with the advent of university courses in 'world philosophy'. Substantial series such as 'Cambridge Texts in the History of Philosophy' (CUP) and 'International Library of Philosophy' (Routledge) in the UK, the 'Philosophical Classics' series from Dover and Hackett in the USA or, in Germany, Felix Meiner Verlag's 'Philosophische Bibliothek' (publishing since 1868, currently with 506 titles) keep translated philosophy titles in print, and smaller presses cater for new translated trends (e.g. L'Éclat, Ithaque and Agone for analytic philosophy in France). The last two decades have seen an explosion of online publication, too, with out-of-copyright translations available from gargantuan e-text collections like Project Gutenberg (www.gutenberg.org) and the Perseus Digital Library (www.perseus.tufts.edu), or philosophy-specific sites such as Early Modern Texts (www.earlymoderntexts.com), the Marxists Internet Archive (www.marxists.org) or Historic Analytic (www.hist-analytic.org). Such freely available resources are supplemented by subscription services such as the Loeb Classical Library (www.loebclassics.com), and with the rise of open access publishing even in-copyright translations are becoming freely available.

\section{Critical issues and topics, i): Why translate philosophy?}

If we revisit Cicero's question from the start of philosophy translation in the West and ask what is its purpose, I would like next to analyse five possible responses. ${ }^{2}$ First, philosophy translation (generally speaking) arises from the intention - on the part of a translator, publisher or other translation commissioner - simply to make a work or body of philosophy available to a new readership who lack command of the source language. This is what Chantal Wright terms the 'humanist case for translation' (Wright 2016: 19-30), and it may 
sound like disinterested cultural mediation, although it is usually motivated by at least an intercultural scholarly interest in promoting an alternative world view, and often a good deal more than that, amounting to the advancement of colonialist and other ideological agendas. Lawrence Venuti writes of the 'ethnocentric violence of translation' (Venuti 1995: 41), and Nietzsche before him writes of Roman poets translating roughshod over their Greek forebears, in an age when 'to translate meant to conquer' (Nietzsche 1992: 69). Examples of this approach range from Cicero advancing his political agenda (Baraz 2012) and the Abbasids looking to assert intellectual primacy over the Byzantines and Persians, to statesponsored translations of Marx and Engels published in Soviet Moscow by Progress Publishers and disseminated worldwide.

A second major aim in philosophy translation has been to use translation as a vehicle for exegesis of the philosophy itself, clarifying ambiguities and resolving cruces through translation choices (in addition to any editorial apparatus that might also be provided). Again, this can seem harmless - e.g. in the mid-20th century J. L. Austin translating Frege for teaching purposes (Frege 1950) - but all translation is more or less overt interpretation, whether consciously or not, and this applies to philosophy as to any other text type. In his translations of Plato, for example, 'Cicero engages in the philosophical interpretation and correction of his original text' (White 2015: 206), and in his Timaeus, 'Cicero is able to subtly manipulate the original Platonic source text to emphasise the similarity of its thought to the doctrines of Pythagoreanism' (White 2015: 304-5). Almost two millennia later another distinguished Plato translator, Benjamin Jowett, openly admits that his general aim 'has been to represent Plato as the father of Idealism' (Jowett 1875, II: 19). Often translators have to wrestle with a term which is ambiguous in the source language and can have multiple translations, resolving the dilemma by opting for one alternative over another - e.g. Peter 
Adamson (2016) points out that Arabic translators of Aristotle had to choose between two different words to translate eidos, depending on whether they thought it meant 'form' or 'species'. English translators of Hegel's Phenomenology (1807) find themselves in a similar quandary when faced with the notorious shibboleth Geist, and end up priming the reader for very different readings of the text by translating the title with either 'mind' (Hegel 1910) or 'spirit' (Hegel 1977). Venuti gives the example of Elizabeth Anscombe's version of Wittgenstein's Philosophical Investigations (1953), and - by analysing lexical choices such as 'philosophical problems arise when language goes on holiday' at PI 38 for 'die philosophischen Probleme entstehen, wenn die Sprache feiert' - points out how Anscombe's translation assimilated Wittgenstein to domestic philosophical taste (Venuti 1998: 107-15). The stakes can be very high indeed with such manipulations (Hermans 1985): in his lectures on Parmenides, Heidegger describes the Latin translation of Greek terms for 'being' as a kind of ontological original sin:

What is decisive is that the Latinization occurs as a transformation of the essence of truth and Being within the essence of the Greco-Roman domain of history. This transformation is distinctive in that it remains concealed but nevertheless determines everything in advance. (Heidegger 1992: 42)

For Heidegger, the creation and adoption of a Latin philosophical vocabulary determined a very different (and in his view baneful) course for the historical development of philosophy itself.

Third, irrespective of the nature and quality of the translation, the infusion of new ideas and forms has invariably had a reinvigorating impact on indigenous philosophical traditions. Reception has usually followed a common path, from translation and commentary to imitation and emulation, to adaptation and syncretistic fusion with native traditions. Such was 
the case with Al-Kindī and his circle in Baghdad, who made the translation of Aristotle into a springboard for developing a distinctive Islamic philosophy; likewise the Kyoto School in 20th-century Japan was a response to contact with 19th-century German thought, synthesised with Asian traditions (Davis 2014). It has been the case over the history of philosophy with all the various translation-led 'neo-philosophies' (neo-Aristotelianism, neo-Platonism, neoHegelianism, etc.), which pass from a revival of interest in an earlier philosopher or movement to a new style of thinking. In some cases the impact has been minor (Nietzsche adopting the word Tschandala to supplement his already extensive multilingual vocabulary of abuse), in others it has been more profound (Schopenhauer's descriptions of the workings of the 'Veil of Maya'). In any event, in this way translation can be genuinely productive even when the target-language philosophy which results is based on poor translations, misunderstandings, skewed or partial (decontextualised) interpretations, or creative misreadings - witness the impact of Alexandre Kojève's Hegel on 20th-century French philosophy (Dale 2014), or the post-War success of Simone de Beauvoir's Le deuxième sexe [The Second Sex] in the English-speaking world despite the patent inadequacies of the 1953 translation by entomologist Howard Madison Parshley (Bogic 2011).

An important consideration for many of the translators reviewed above, from Lucretius and Cicero to King Alfred and Étienne Dolet, was the desire to enrich a fledgling vernacular at a crucial point in its emergence as a literary language, to oblige one's language to think about the world differently. With the emergence of European literary vernaculars in the Renaissance period, Italian, French, Spanish and English were initially prominent and German was rather slower off the mark, but German developed in the course of the 18th century - i.e. after Leibniz, who wrote mainly in Latin and French - to become the European language of philosophy par excellence, largely through the work of Christian Thomasius 
(1655-1728) and Christian Wolff (1679-1754). Eric Blackall writes that 'Wolff's German terminology translates into the natural speech material of his day the meaning of the Latin concepts, or of the new distinctions which he is introducing' (Blackall 1959: 33). Just as Cicero championed Latin over Greek, now Wolff believed that German was a better language for scholarship than Latin (Blackall 1959: 37). In turn, 'his works were the first scholarly works in German to be translated into several languages' (Blackall 1959: 47), and it was Wolff who by such means prepared the way for Kant in the next generation to forge a new vocabulary once again.

A fifth benefit from philosophy translation is developing and extending the philosophical horizons of individual translators. Many apprentice philosophers have produced translations of philosophical works at the beginning of their careers as a way of cutting their teeth, and then gone on to greatness (Large 2014). Not that they are necessarily translating for publication or circulation, either - they might be translating out of sheer intellectual curiosity and for personal pleasure, or for other distinctly personal motives, as with the 60 -year-old Queen Elizabeth I, who translated Boethius into early modern English at Windsor Castle in 1593 as a projection of intellectual power and in order to earn the respect of her courtiers for the speed with which she worked (Benkert 2001).

\section{Critical issues and topics, ii): Who translates philosophy?}

This brings us to the question of who translates philosophy. In the history of philosophy translation, a figure like Elizabeth I has always been an exception - and not just because she was a ruling monarch or a woman, but because she was a non-specialist. Philosophy is a very specialised literary genre with (for the most part) a specialised readership. It has always been 
regarded as one of the most demanding kinds of translation, requiring specialist technical knowledge. As early as 1531 the Spanish humanist Juan Luis Vives argued: 'The works of Aristotle will be badly translated by a man who is not a philosopher and those of Galen by a man who is not a doctor' (Vives 2002: 92). Such an argument resembles the parallel claim that poetry translation needs to be done by poets, but - as with poetry - it doesn't necessarily follow that the strongest, most original exponents of the art will produce the best translations. For example, J. L. Austin's translation of Frege's Foundations of Arithmetic has been criticised by its more recent translator, Dale Jacquette:

Austin's translation has served to introduce several generations of students to Frege's ideas, and has endeared itself to its readers for its fluidity and charm. Frege himself, unfortunately, is not quite as charming as Austin's translation portrays, and Austin does not always faithfully represent or seem to perfectly understand certain of Frege's German idioms. It is worth remembering that Austin's translation was originally prepared as lecture notes for students, and that Austin was not otherwise known as having a special interest in German literature or philosophy. (Jacquette 2016: v)

Many of the world's greatest philosophers have translated the works of others, and translated them well, whether cutting their teeth in a philosophical apprenticeship or as established figures (Large 2014). Philosophy translators have often not been philosophers of the first rank themselves, though; nor have they necessarily been academics (e.g. the autodidact Nietzsche translator R. J. Hollingdale, whose day job was as an editor for the Guardian newspaper). Some significant modern philosophical translations have been carried out by jobbing professional literary translators (e.g. Ralph Manheim’s Heidegger 1959 or Shaun Whiteside's Nietzsche 1993), but these constitute exceptions. After all, no translator makes a great deal of money out of translating philosophical texts: they do not turn into bestsellers, as a rule, and any aspiring professional translator will need to make their living mostly by other means. As a result most modern philosophy translations are carried out by moonlighting academics (who 
do not need the money), to support their pedagogy or the development of their research careers - what Alastair Hannay, surveying Kierkegaard translations, calls 'not professional translators but scholars who have felt a rapport with the writing and feel impelled to bring [it] to the notice of contemporaries' (Hannay 2013: 387).

The perceived difficulty of philosophy translation has lent it an undoubted prestige, which goes some way to explaining its attraction over the years to high-class amateur translators such as King Alfred and Queen Elizabeth I. In the historical period other women philosophy translators have been few, given their exclusion from the universities. Notable Enlightenment translations by women include the German translations of Bayle, Leibniz and Hobbes by Luise Gottsched (Brown 2012: 48-60), the English Epictetus of Elizabeth Carter (1717-1806) (Agorni 2005) and the French translation of Adam Smith's Theory of Moral Sentiments by Sophie de Condorcet (1764-1822); then in the 19th and early 20th centuries stand-outs include George Eliot's Spinoza and Feuerbach, the Bhagavad Gita of Annie Besant (18471933), the Plato translations of Ellen Francis Mason (1846-1930) and Elizabeth Haldane's (1862-1937) Descartes and Hegel. In the post-War period many significant contributions have been made by women translators: for example Suzanne Bachelard, Françoise Dastur, Monique Wittig and Françoise Wuilmart in the French-speaking world; in the Englishspeaking world Elizabeth Anscombe, Hazel Barnes, Seyla Benhabib, Mary J. Gregor, Peggy Kamuf, Susanne Langer, Gayatri Chakravorty Spivak, Joan Stambaugh and Barbara Stoler Miller.

\section{Critical issues and topics, iii): How to translate philosophy?}


In the light of the rich history of practical philosophy translation work detailed above, it may seem surprising that theorists of translation have so often concluded that philosophy is untranslatable (Large 2018). The history of reflection on the translation of philosophy has been dominated by the question of translation difficulty, and it has been widely recognised that philosophical texts pose a particular challenge to the translator, comparable to translating scripture or poetry. Kant in English translation, say, is not 'the same' as Kant in German, no one-to-one equivalence is possible, and the failure to achieve exact correspondence in the translation of philosophical terms has often led to purist cries of untranslatability. Barbara Cassin's recent Dictionary of Untranslatables (Cassin 2014) is (for the most part) a dictionary of concepts, and what commentators usually mean when they call philosophy untranslatable is its rigorous conceptual language, for that is what marks the specificity of philosophy (and, with it, philosophy translation) in the first place. But technical terms will often have agreed equivalents in a target language (e.g. Kantian Anschauung = 'intuition’), even if such agreement is by no means always reached and can in any case mask a great deal of approximation. Philosophy is a broad domain which encompasses many other kinds of language, too: as Jonathan Rée puts it, 'the arts of philosophical writing overlap in many ways with the practices of storytelling' (Rée 2001: 227), and those texts which place a greater emphasis on exploiting the expressive potential of a particular natural language (e.g. through frequent use of metaphor and other rhetorical tropes) often pose translation difficulties which are at least as great. It may be essential to work out the precise meaning of, say, sophrosune [prudence, temperance] in the classical canon, but in poring over concepts it is easy to forget that, as Leonardo Bruni was pointing out as early as the 15th century:

Aristotle himself and Plato were, I may say, the very greatest masters of Literature, and practiced a most elegant kind of writing filled with the sayings and maxims of the old poets and orators and historians, and frequently employed tropes and figures of 
speech that have acquired idiomatic meanings far different from their literal meanings. (Bruni 2002: 58)

As with poetry translation, though, the greater the difficulty, the more opportunity for adventurousness and experimentation. At the outset of vernacular traditions, as we have seen (Lucretius and Cicero, Chaucer, Wolff and Kant), translators placed in a position of maximal foreign exposure have responded with considerable creativity and ingenuity, by importing foreign vocabulary wholesale, perhaps, or creating conceptual neologisms and calques. Nor has this stopped with the first wave of translations: in 1855 the 19-year-old John Meiklejohn writes in the 'Translator's Preface' to his new English translation of Kant's First Critique: 'it has been found requisite to coin one or two new philosophical terms, to represent those employed by Kant. It was, of course, almost impossible to translate the Kritik with the aid of the philosophical vocabulary at present used in England' (Meiklejohn 1855: xii). Something similar occurs in the 20th century with Spivak's Derrida (1976) - it is not just at the start of a vernacular tradition that a philosopher can choose to neologise rebarbatively and ask questions of the translator('s creativity).

Derrida coined the French term déconstruction as a calque on Heidegger's German terms Abbau and Destruktion (Derrida 1985: 86-7), and Heidegger's own writings are determinedly neologistic - not because he is at the start of a vernacular tradition of philosophising, but because he is deliberately turning his back on the tradition and starting again with (German) language's relation to a thinking of Be-ing. Generations of Heidegger translators have met the challenge of his language more or less successfully, but Heidegger translation reached a crisis with the publication of the first English translation of the Beiträge at the turn of the millennium. Parvis Emad and Kenneth Maly's highly controversial translation of Beiträge zur Philosophie (Vom Ereignis) as Contributions to Philosophy: From Enowning (Heidegger 
1999) took Heideggerian neologising to a new extreme. They approached the text with a hyperbolic reverence, intent (in true Heideggerian fashion) on bringing out/forging etymological resonances, even (in fact, generally) at the expense of the sense of the target language standard. Earlier in the 20th century, following Carnap, English-language analytic philosophy had pilloried Heidegger's 'nothing noths' as the epitome of empty metaphysics (even if that precise phrase was never published as a translation of 'Das Nichts selbst nichtet'), but this was something else again:

Time-space is the enowned encleavage of the turning trajectories [Kehrungsbahnen] of enowning, of the turning between belongingness and the call, between abandonment by being and enbeckoning (the enquivering of the resonance of be-ing itself!). (Heidegger 1999: 260)

Simon Blackburn was not impressed by the mystical/mystificatory tone of this translation and published a damning review (Blackburn 2000), but even fellow-Heideggerians thought Emad and Maly had gone too far. Richard Polt (himself a distinguished Heidegger translator) comments:

the translators have resorted to neologisms too often. I prefer to use established English words while allowing their connotations to adapt to a new context. Heidegger himself usually adopts normal words (such as Ereignis and Wesen), so that even though these words gain new meanings in his experiments, they retain a connection to the old. Language opens fresh horizons by drawing creatively on its own heritage not by breaking with it. (Polt 2013: 9)

The controversy eventually resulted in the publication - by the same publisher (Indiana University Press) - of a new, more conservative translation by Richard Rojcewicz and Daniela Vallega-Neu as the 'official' translation for the Heidegger Gesamtausgabe in English (Heidegger 2012). As in this case, retranslations have often been drier, more dutiful, and 
tended to err on the side of literalness - although that is not to say that, as with the King James Version of the Bible, there are not also readers who prefer an earlier translation for literary or other reasons (e.g. Meiklejohn or Kemp Smith's translations of Kant's First Critique over the more recent versions by Pluhar or Guyer and Wood). Unusually, in the case of Heidegger's Contributions, the publisher does not consider the second translation to have superseded the first, and the two versions are both still in print, offering the aspirant reader a choice between two very different translation strategies. (See Chapter 3.)

\section{Conclusion: future directions}

Heidegger in English has become the 'poster boy' for creative style in philosophy translation. David Farrell Krell's 1975 translation of Heidegger's essay 'The Anaximander Fragment' which includes sentences like 'The surmounting of disorder properly occurs through the letting-belong of reck' (Heidegger 1975: 47) - is cited approvingly by Venuti as his example par excellence of an experimental translation style which at the same time accords with Heidegger's own 'poetising' translation strategy (Venuti 1998: 119-22). Employing the concept of 'the remainder, the collective force of linguistic forms that outstrips any individual's control and complicates intended meanings' (Venuti 1998: 108), Venuti concludes with a call to arms for philosophy translators to be more creative:

The translation of philosophical texts can be improved, and the issue of translation productively introduced in philosophical interpretation, if translators take a more experimental approach to their work. [...] However unpredictable the remainder may ultimately be, it nonetheless requires translators to respond creatively to the stylistic pressures exerted by the philosophical project of concept formation. (Venuti 1998: 122) 
It would seem to me that not very many other philosophers lend themselves to being translated in the way Venuti recommends. The kind of experimental translation strategy practised by many of Heidegger's English translators is licensed by the source text author's creativity with language in the first place, putting the translator in the same position as the translator of some of Heidegger's favourite poets (notably Friedrich Hölderlin), whose style he was ultimately imitating. ${ }^{3}$ Experimental translation strategies have been most successful and appropriate with poetic material, or with highly opaque, self-reflexive prose like Joyce's Finnegans Wake (O’Neill 2013; cf. Tawada 2013), so it is not surprising if they have had their most signal successes with philosophy at the more poetic end of the stylistic spectrum (another example is Peter Glassgold's Boethius 1994). Generally speaking, though, the kind of fireworks available from Krell or Emad and Maly are not available for other philosophers, and because of the nature of the subject matter, philosophical translators have tended to prioritise terminological precision and consistency above all else. In this respect it is surprising that translators (and their publishers) have not exploited more the hypertextual possibilities available online. Kevin C. Klement's innovative 'Side-by-Side-by-Side Edition' of Wittgenstein's Tractatus sets the original German alongside the two standard English versions, the Ogden (or Ogden/Ramsey) translation (1922), and the Pears/McGuinness translation (1961): the result is undoubtedly hugely helpful to the scholar, but the translations themselves are unchanged.

Be that as it may, Venuti's starting point is that translation is not often enough thematised within philosophical study, and that can be addressed - the translator can be made more visible - even without flamboyantly drawing attention to the translatedness of 'foreign philosophy' through furiously foreignising translations. For all too long commentators have been regretting translation loss, but one of the important aspects of the impact of translation 
studies on philosophy has been an increased willingness to acknowledge possibilities of translation gain, and always to expect translation difference. The ultimate interest of a project like Barbara Cassin's Dictionary of Untranslatables (Cassin 2014) lies not so much in drawing attention once again to the straw man that is the supposed untranslatability of philosophical concepts, but in fostering a greater recognition of the extraordinary intellectual achievement that is actually involved in the translation of philosophical texts.

\section{Related topics}

Nietzsche; Heidegger; Wittgenstein; Derrida; current trends in philosophy and translation; equivalence; translating feminist philosophers; Shelley's Plato; translating Kant and Hegel; translating Derrida; Levinas: his philosophy and its translation

\section{Further reading}

Large, Duncan, 'On the Work of Philosopher-Translators', in Jean Boase-Beier, Antoinette Fawcett and Philip Wilson (eds), Literary Translation: Redrawing the Boundaries (Houndmills and New York: Palgrave Macmillan, 2014), 182-203. (A study of the way many major philosophers have, like poet-translators, developed their own distinctive style through translating the works of others.)

Rée, Jonathan, 'The Translation of Philosophy', New Literary History, 32/2 (2001), 223-57. (The best single article on this topic: a superb treatment of many of the issues raised by the translation of philosophy, with plenty of examples.) 
Venuti, Lawrence, 'Philosophy', in The Scandals of Translation: Towards an Ethics of Difference (London and New York: Routledge, 1998), 106-23. (A leading translation theorist calls for a more experimental style of philosophy translation, with impressive analyses of translations of Wittgenstein and Heidegger.)

Young, Robert J. C., 'Philosophy in Translation', in Sandra Bermann and Catherine Porter (eds), A Companion to Translation Studies (Chichester: Wiley Blackwell, 2014), 41-53. (A lucid account of some of the key issues in the historical encounter between philosophy and translation, by one of the leading postcolonialist theorists.)

\section{References}

Adamson, Peter, Al-Kindī (Oxford and New York: Oxford University Press, 2007).

Adorno, Theodor W., Kierkegaard: Construction of the Aesthetic, ed. and trans. Robert Hullot-Kentor (Minneapolis: University of Minnesota Press, 1989).

Agorni, Mirella, 'A Marginal(ized) Perspective on Translation History: Women and Translation in the Eighteenth Century', Meta, 50/3 (August 2005), 817-30.

Akasoy, Anna and Guido Giglioni (eds), Renaissance Averroism and Its Aftermath: Arabic Philosophy in Early Modern Europe (Dordrecht: Springer, 2013).

Al-Khalili, Jim, The House of Wisdom: How Arabic Science Saved Ancient Knowledge and Gave Us the Renaissance (New York: Penguin, 2011).

Alwishah, Ahmed and Josh Hayes (eds), Aristotle and the Arabic Tradition (Cambridge: Cambridge University Press, 2015).

Anquetil, Jacques, Anquetil-Duperron: premier orientaliste français (Paris: Presses de la Renaissance, 2005).

Anquetil-Duperron, Abraham Hyacinthe, ed. and trans., Zend-Avesta, ouvrage de Zoroastre, 3 vols in 2 (Paris: N. M. Tilliard, 1771).

Anquetil-Duperron, Abraham Hyacinthe, ed. and trans., Oupnek'hat (id est Secretum tegendum), 2 vols (Strasbourg: Argentorati, 1801-2). 
Baraz, Yelena, 'The Gift of Philosophy: The Treatises as Translations', in A Written Republic: Cicero's Philosophical Politics (Princeton, NJ and Woodstock: Princeton University Press, 2012), 96-127.

Brandt, Bettina and Daniel Leonhard Purdy (eds), China in the German Enlightenment (Toronto, Buffalo and London: University of Toronto Press, 2016).

Bianchi, Luca, Simon Gilson and Jill Kraye (eds), Vernacular Aristotelianism in Italy from the Fourteenth to the Seventeenth Century (London: Warburg Institute, 2016).

Blackall, Eric A., 'The Language of Philosophy', in The Emergence of German as a Literary Language 1700-1775 (Cambridge: Cambridge University Press, 1959), 19-48.

Blackburn, Simon, 'Enquivering', The New Republic, 30 October 2000, 43-48.

Blocker, H. Gene and Christopher L. Starling, Japanese Philosophy (Albany: State University of New York Press, 2001).

Boethius, The Poems from 'On the Consolation of Philosophy', Translated Out of the Original Latin into Diverse Historical Englishings Diligently Collaged by Peter Glassgold, (Los Angeles: Sun \& Moon Press, 1994).

Bogic, Anna, 'Why Philosophy Went Missing: Understanding the English Version of Simone de Beauvoir's Le deuxième sexe', in Luise von Flotow (ed.), Translating Women (Ottawa: University of Ottawa Press, 2011), 151-66.

Brobjer, Thomas H., Nietzsche's Philosophical Context: An Intellectual Biography (Urbana and Chicago: University of Illinois Press, 2008).

Brown, Hilary, Luise Gottsched the Translator (Rochester, NY: Camden House, 2012).

Bruni, Leonardo, On the Correct Way to Translate, trans. James Hankins, in Douglas Robinson (ed.), Western Translation Theory from Herodotus to Nietzsche, 2nd edn (Manchester and Northampton, MA: St Jerome, 2002), 57-60.

Cartwright, David E., Schopenhauer: A Biography (Cambridge: Cambridge University Press, 2010).

Catullus, Gaius Valerius, The Complete Poetry, trans. Frank O. Copley (Ann Arbor: University of Michigan Press, 1957).

Cassin, Barbara (ed.), Dictionary of Untranslatables: A Philosophical Lexicon, trans. Steven Rendall et al. (Princeton and Oxford: Princeton University Press, 2014).

Cicero, Marcus Tullius, On Old Age; and On Friendship, trans. Frank O. Copley (Ann Arbor: University of Michigan Press, 1967).

Clay, Diskin, Lucretius and Epicurus (Ithaca, NY and London: Cornell University Press, 1983). 
Clay, Diskin, 'Recovering Originals: Peri Physeos and De Rerum Natura', Apeiron 33/3 (2000), 259-71.

Collado, Jesús-Antonio, Kierkegaard y Unamuno: la existencia religiosa (Madrid: Gredos, 1962).

Copenhaver, Brian P., 'Translation, Terminology and Style in Philosophical Discourse', in Charles B. Schmitt and Quentin Skinner (eds), The Cambridge History of Renaissance Philosophy (Cambridge and New York: Cambridge University Press, 1988), 77-110.

Couplet, Philippe (ed.), Confucius Sinarum Philosophus, sive, Scientia Sinensis Latine Exposita (Paris: Daniel Horthemels, 1687).

Dale, Eric Michael, 'Hegel and Kojève', in Hegel, the End of History, and the Future (Cambridge and New York: Cambridge University Press, 2014), 80-110.

Davis, John R. and Angus Nicholls (eds), Friedrich Max Müller and the Role of Philology in Victorian Thought (London and New York: Routledge, 2017).

Davis, Walter W., 'China, the Confucian Ideal, and the European Age of Enlightenment', Journal of the History of Ideas, 44/4 (1983), 523-48.

Delisle, Jean and Judith Woodsworth (eds), Translators through History, 2nd edn (Amsterdam and Philadephia: John Benjamins, 2012).

Demetriou, Tania and Rowan Tomlinson (eds), The Culture of Translation in Early Modern England and France, 1500-1660 (Houndmills and New York: Palgrave Macmillan, 2015).

De Pol, Roberto (ed.), The First Translations of Machiavelli's 'Prince': From the Sixteenth to the First Half of the Nineteenth Century (Amsterdam and New York: Rodopi, 2010).

Derrida, Jacques, Of Grammatology, trans. Gayatri Chakravorty Spivak (Baltimore, MD and London: Johns Hopkins University Press, 1976).

Derrida, Jacques, The Ear of the Other: Otobiography, Transference, Translation, ed. Christie V. McDonald, trans. Peggy Kamuf (New York: Schocken Books, 1985).

Deussen, Paul (ed. and trans.), Die Sūtra's des Vedānta, oder die Çārīraka-Mìmāñsā des Bādarāyaṇa nebst dem vollständigen Kommentare des C,ankkara (Leipzig: Brockhaus, 1887).

Discenza, Nicole Guenther, The King's English: Strategies of Translation in the Old English 'Boethius' (Albany: State University of New York Press, 2005).

Dolet, Etienne, 'Extracts from De la manière de bien traduire d'une langue en autre ("On the Way of Translating Well from One Language into Another"')', in André Lefevere (ed.), Translation/History/Culture: A Sourcebook (London and New York: Routledge, 1992), 27-8.

Elst, Koenraad, 'Manu as a Weapon against Egalitarianism: Nietzsche and Hindu Political Philosophy', in Herman W. Siemens and Vasti Roodt (eds), Nietzsche, Power and Politics: 
Rethinking Nietzsche's Legacy for Political Thought (Berlin and New York: De Gruyter, 2008), 543-82.

Franklin, Michael J., Orientalist Jones: Sir William Jones, Poet, Lawyer, and Linguist, 17461794 (Oxford and New York: Oxford University Press, 2011).

Frege, Gottlob, The Foundations of Arithmetic: A Logico-Mathematical Enquiry into the Concept of Number, trans. J. L. Austin (Oxford: Basil Blackwell, 1950).

Girardot, Norman J., The Victorian Translation of China: James Legge's Oriental Pilgrimage (Berkeley, Los Angeles and London: University of California Press, 2002).

Gutas, Dimitri, Greek Thought, Arabic Culture: The Graeco-Arabic Translation Movement in Baghdad and Early 'Abbāsid Society (2nd-4th/8th-10th Centuries) (London and New York: Routledge, 1998).

Hannay, Alastair, 'Translating Kierkegaard', in John Lippitt and George Pattison (eds), The Oxford Handbook of Kierkegaard (Oxford: Oxford University Press, 2013), 385-401.

Harvey, David Allen, 'The Wisdom of the East: Enlightenment Perspectives on China', in The French Enlightenment and Its Others: The Mandarin, the Savage, and the Invention of the Human Sciences (Basingstoke: Palgrave Macmillan, 2012), 41-68.

Hegel, G. W. F., The Phenomenology of Mind, trans. J. B. Baillie (London and New York: Macmillan, 1910).

Hegel, G. W. F., The Phenomenology of Spirit, trans. A. V. Miller (Oxford: Clarendon Press, 1977).

Heidegger, Martin, An Introduction to Metaphysics, trans. Ralph Manheim (New Haven: Yale University Press; London: Oxford University Press, 1959).

Heidegger, Martin, 'The Anaximander Fragment', trans. David Farrell Krell, in Early Greek Thinking, trans. David Farrell Krell and Frank A. Capuzzi (New York: Harper \& Row, 1975), 13-58.

Heidegger, Martin, Hegel's Phenomenology of Spirit, trans. Parvis Emad and Kenneth Maly (Bloomington and Indianapolis: Indiana University Press, 1988).

Heidegger, Martin, Parmenides, trans. André Schuwer and Richard Rojcewicz (Bloomington and Indianapolis: Indiana University Press, 1992).

Heidegger, Martin, Contributions to Philosophy (From Enowning), trans. Parvis Emad and Kenneth Maly (Bloomington and Indianapolis: Indiana University Press, 1999).

Heidegger, Martin, Contributions to Philosophy (Of the Event), trans. Richard Rojcewicz and Daniela Vallega-Neu (Bloomington and Indianapolis: Indiana University Press, 2012).

Herling, Bradley L., The German Gita: Hermeneutics and Discipline in the German Reception of Indian Thought, 1778-1831 (New York and London: Routledge, 2006). 
Hermans, Theo (ed.), The Manipulation of Literature: Studies in Literary Translation (London: Croom Helm; New York: St. Martin's Press, 1985).

Hoenen, Maarten J. F. M. and Lodi Nauta (eds), Boethius in the Middle Ages: Latin and Vernacular Traditions of the 'Consolatio Philosophiae' (Leiden: Brill, 1997).

Hullot-Kentor, Robert, 'Translator's Introduction', in Theodor W. Adorno, Aesthetic Theory, ed. Gretel Adorno and Rolf Tiedemann, trans. Robert Hullot-Kentor (Minneapolis:

University of Minnesota Press, 1997), xi-xxi.

Hung, Eva and David Pollard, 'Chinese Tradition', in Mona Baker (ed.), Routledge Encyclopedia of Translation Studies (London and New York: Routledge, 1998), 365-76.

Jacolliot, Louis (ed. and trans.), Les législateurs religieux: Manou, Moïse, Mahomet (Paris: Lacroix, 1876).

Jacquette, Dale, 'Preface', in Gottlob Frege, Foundations of Arithmetic, trans. Dale Jacquette, 2nd edn (London and New York: Routledge, 2016), v-vi.

Jones, Howard, Master Tully: Cicero in Tudor England (Nieuwkoop: De Graaf, 1998).

Karyekar, Madhuvanti Chintamani, 'Hegel and the Latin Bhagavadgītā (1823): A Critique of Understanding and Translating the Foreign', in Federico M. Federici and Dario Tessicini (eds), Translators, Interpreters, and Cultural Negotiators: Mediating and Communicating Power from the Middle Ages to the Modern Era (Houndmills and New York: Palgrave Macmillan, 2014), 155-72.

Large, Duncan, 'On the Work of Philosopher-Translators', in Jean Boase-Beier, Antoinette Fawcett and Philip Wilson (eds), Literary Translation: Redrawing the Boundaries (Houndmills and New York: Palgrave Macmillan, 2014), 182-203.

Large, Duncan, 'The Untranslatable in Philosophy', in Duncan Large, Motoko Akashi, Wanda Józwikowska and Emily Rose (eds), Untranslatability: Interdisciplinary Perspectives (New York and London: Routledge, 2018), forthcoming.

Legge, James (ed. and trans.), The Chinese Classics: with a Translation, Critical and Exegetical Notes, Prolegomena, and Copious Indexes, 5 vols (Hong Kong: Legge; London: Trübner, 1861-72).

Legge, James (ed. and trans.), The Sacred Books of China, 6 vols (Oxford: Clarendon Press, 1879-91).

Lucretius, The Nature of Things, trans. A. E. Stallings (London: Penguin, 2007).

Lyons, Jonathan, The House of Wisdom: How the Arabs Transformed Western Civilization (New York and London: Bloomsbury, 2009).

Mander, W. J., British Idealism: A History (Oxford and New York: Oxford University Press, 2011). 
Mayuko, Uehara (ed.), Philosopher la traduction / Philosophizing Translation (Nagoya: Chisokudō, 2017).

Meiklejohn, J. M. D., 'Translator's Preface', in Immanuel Kant, Critique of Pure Reason, trans. J. M. D. Meiklejohn (London: Henry G. Bohn, 1855), xi-xv.

Molendijk, Arie L., Friedrich Max Müller and the 'Sacred Books of the East' (Oxford and New York: Oxford University Press, 2016).

Müller, F. Max (ed.), Rig-Veda-Sanhita: The Sacred Hymns of the Brahmans, Together with the Commentary of Sayanacharya, 6 vols (London: W. H. Allen, 1849-1874).

Müller, F. Max (ed.), The Sacred Books of the East, 50 vols (Oxford: Clarendon Press, 18791910).

Müller, F. Max (ed. and trans.), The Upanishads, 2 vols (Oxford: Clarendon Press, 1879-84).

Mungello, D. E., 'European Acceptance of Chinese Culture and Confucianism', in The Great Encounter of China and the West, 1500-1800, 4th edn (Lanham, MD: Rowman \& Littlefield, 2013), 91-122.

Nietzsche, Friedrich, 'On the Problem of Translation', trans. Peter Mollenhauer, in Rainer Schulter and John Biguenet (eds), Theories of Translation: An Anthology of Essays from Dryden to Derrida (Chicago and London: University of Chicago Press, 1992), 68-70.

Nietzsche, Friedrich, The Birth of Tragedy Out of the Spirit of Music, trans. Shaun Whiteside, ed. Michael Tanner (Harmondsworth: Penguin, 1993).

O’Neill, Patrick, Impossible Joyce: Finnegans Wakes, 3rd edn (Totonto, Buffalo and London: University of Toronto Press, 2013).

Parkes, Graham (ed.), Nietzsche and Asian Thought (Chicago and London: University of Chicago Press, 1991).

Perkins, Franklin, Leibniz and China: A Commerce of Light (Cambridge: Cambridge University Press, 2004).

Petrina, Alessandra, Machiavelli in the British Isles: Two Early Modern Translations of 'The Prince' (Farnham: Ashgate, 2009).

Plato, The Dialogues of Plato, ed. and trans. Benjamin Jowett, 5 vols (Oxford: Clarendon Press, 1875).

Polt, Richard, The Emergency of Being: On Heidegger's 'Contributions to Philosophy' (Ithaca, NY and London: Cornell University Press, 2013).

Rathore, Aakash Singh and Rimina Mohapatra, Hegel's India: A Reinterpretation, with Texts (New Delhi: Oxford University Press, 2017). 
Rée, Jonathan, 'The Translation of Philosophy', New Literary History, 32/2 (2001), 223-57.

Rose, Jenny, 'Thus Spoke Nietzsche', in The Image of Zoroaster: The Persian Mage Through European Eyes (New York: Bibliotheca Persica Press, 2000), 173-94.

Schlegel, August Wilhelm (ed.), Bhagavad-Gita (Bonn: Weber, 1823).

Schlegel, Friedrich, Ueber die Sprache und Weisheit der Indier: Ein Beitrag zur Begründung der Alterthumskunde; Nebst metrischen Übersetzungen Indischer Gedichte (Heidelberg:

Mohr und Zimmer, 1808).

Sedley, David, Lucretius and the Transformation of Greek Wisdom (Cambridge: Cambridge University Press, 1998).

Seele, Astrid, Römische Übersetzer: Nöte, Freiheiten, Absichten. Verfahren des literarischen Übersetzens in der griechisch-römischen Antike (Darmstadt: Wissenschaftliche Buchgesellschaft, 1995).

Stanton, Robert, The Culture of Translation in Anglo-Saxon England (Cambridge: D. S. Brewer, 2002).

Strindberg, August, Tschandala, trans. Peter Nansen (Copenhagen: I. H. Schubothe, 1889).

Tawada, Yoko, Portrait of a Tongue: An Experimental Translation, trans. Chantal Wright (Ottawa: University of Ottawa Press, 2013).

Venuti, Lawrence, The Translator's Invisibility: A History of Translation (London and New York: Routledge, 1995).

Venuti, Lawrence, 'Philosophy', in The Scandals of Translation: Towards an Ethics of Difference (London and New York: Routledge, 1998), 106-23.

Vives, Juan Luis, 'Practice in Writing', trans. Foster Watson, in Douglas Robinson (ed.), Western Translation Theory from Herodotus to Nietzsche, 2nd edn (Manchester and Northampton, MA: St Jerome, 2002), 92.

White, Georgina Frances, unpublished PhD diss., 'Copia verborum: Cicero's Philosophical Translations' (Princeton University, 2015).

Wittgenstein, Ludwig, Philosophical Investigations, trans. G. E. M. Anscombe (Oxford: Basil Blackwell, 1953).

Worth, Valerie, Practising Translation in Renaissance France: The Example of Étienne Dolet (Oxford: Clarendon Press, 1988).

Wright, Chantal, Literary Translation (London and New York: Routledge, 2016).

\section{Webography}


Adamson, Peter, 'Arabic Translators Did Far More Than Just Preserve Greek Philosophy', 4 November 2016 - https://aeon.co/ideas/arabic-translators-did-far-more-than-just-preservegreek-philosophy

D’Ancona, Cristina, 'Greek Sources in Arabic and Islamic Philosophy', Stanford

Encyclopedia of Philosophy, 2017 - https://plato.stanford.edu/entries/arabic-islamic-greek/

Benkert, Lysbeth, 'Translation as Image-Making: Elizabeth I's Translation of Boethius's Consolation of Philosophy', Early Modern Literary Studies, 6/3 (January 2001), 2.1-20 https://extra.shu.ac.uk/emls/06-3/benkboet.htm

Davis, Bret W., 'The Kyoto School', Stanford Encyclopedia of Philosophy, 2014 https://plato.stanford.edu/entries/kyoto-school/

Early Modern Texts - http://www.earlymoderntexts.com/

Historic Analytic - http://www.hist-analytic.org/

Loeb Classical Library - https://www.loebclassics.com/

Marxists Internet Archive - https://www.marxists.org/

Perseus Digital Library - http://www.perseus.tufts.edu/

Project Gutenberg - https://www.gutenberg.org/

Wittgenstein, Ludwig, Tractatus Logico-Philosophicus, ed. Kevin C. Klement https://people.umass.edu/klement/tlp/

\footnotetext{
${ }^{1}$ Spanish novelist and philosopher Miguel de Unamuno, for one, thought it worth the effort (Collado 1962). Adorno - who wrote a dissertation on Kierkegaard (1989) - didn't.

2 Though not exactly an aim of philosophy translation, one of the unintended consequences down the years has been preserving the translated philosophy from not just neglect but oblivion. Lucretius' poem is used as a means of recovering lost texts by Epicurus (Clay 2000), and Cicero's translations of Aristotle are used as a source for reconstructing the Greek (White 2015: 212-30). A number of Aristotle's works have come down to us only because of their Arabic translations (Alwishah and Hayes 2015), and many otherwise lost Sanskrit texts have been preserved in translation in Tibetan and Chinese (Hung and Pollard 1998).

${ }^{3}$ Emad and Maly's earlier translation of Heidegger's lectures on Hegel's Phenomenology (Heidegger 1988) is much more conventional, as befits a source text style that is itself a good deal less freewheeling than in Heidegger's unpublished notebooks. Likewise Frank O. Copley's translations of Cicero (1967) are much less exuberant and adventurous than his versions of Catullus from a decade earlier (1957).
} 